\title{
Algorithms of blended learning in IT education
}

\author{
Olena Kovalenko \\ department of software \\ Vinnytsia national technical university \\ Vinnytsia, Ukraine \\ ok@vntu.edu.ua
}

\author{
Yevgen Palamarchuk \\ department of Automation and Information and \\ Measurement Technology \\ Vinnytsia national technical university \\ Vinnytsia, Ukraine \\ p@vntu.edu.ua
}

\begin{abstract}
The urgency of the research. Blended learning is a modern trend in education. It enables the formation of synergies between traditional educational communications, electronic information dialogues and appeals to electronic resources. The effectiveness of introducing of blended learning in IT education depends not only on the adaptation of known approaches but also on the IT readiness of students and teachers, as well as the use of a variety of tools for modern learning management systems.
\end{abstract}

Target setting. System algorithms of blended learning allow to use the method of "small steps" and to create a composition of interrelated educational processes. The purpose of the study is to identify key processes, roles of learners, learning situations and outcomes. Information models allow to make changes in the components of the management training platform and to correct the methodology of IT disciplines teaching.

Actual scientific researchers and issues analysis. A number of scientific and practical knowledge of authors and their practical experience are the base of this research and the introduction of its results into a practical educational process. Among them are the implementation of the method of "inverted class", the active involvement of specialists and the formation of simulation model of practical activity students for future.

Uninvestigated parts of general issues defining. The large amount of electronic resources, IT tasks and specializations leads to two wrong directions in IT education. One of them is general training which contains abstract examples of practical use. Another is a narrow specialization in the language of programming or development. To determine the balance of fundamental and practical training of an IT specialist is possible by structuring of educational role processes. The peculiarities of self-development in the direction of the management education platform and the teaching experience of the authors are the basis for making changes in the well-known approaches in blended learning of IT education.

The research objective. The purpose of the study is to identify key educational processes, to find algorithms of using internal and external electronic resources, to investigate the algorithms of blended learning, for example, how to make correct improvements in lectures, laboratory and practical classes.

The statement of basic materials. The algorithms of blended learning are based on introducing of changes into traditional forms such as lectures, laboratory, practical classes, their active using of self-training the possibilities of students, the active using of their own practical experience and the best practices of IT industry specialists and IT departments of enterprises of other industries. The introduction of the proposed algorithms is tested during the teaching of disciplines "Algorithms and Data Structures", "Fundamentals of Software Engineering", "Project Management", "Computer Networks" etc. The main changes in educational processes are : using of special network simulation software and project management software; using new approaches tests construction and encouraging students their mastering; the students` individual and teamwork in an education management system environment.

Conclusions. The results of the research consist of determining role-based behavioural educational processes in management of education systems. The new opportunities for dynamics of improving of educational resources is based on involving practitioners, the using of open distance courses and the using of new forms of work with students. The question of activating the role of employers in the educational process and involving them in the evaluation of students' work, as well as the introduction of real cases, is an important issue.

Keywords blended learning, computer discipline, IT enterprise, IT education; IT department; inverted class; learning management system, JetIQ-project.

\section{URGENCY OF THE RESEARCH.}

The urgency of the approaches of blended learning is confirmed by many results of practical research and the tendency of increasing the open resources in education [1-3]. The development of e-learning platforms, industry groups in social networks and open e-learning resources is the basis for the formation of a personal educational environment and a self-education system [4-8]. Such a system requires not only a high level of student motivation but also needs special technical and methodological skills.

\section{TARGET SETTING.}

The formed mixed training course as an updated traditional course that contains a personal learning environment. The student has clear algorithms of assistance in the process of performing independent tasks and an orientation map of electronic training courses. Blended learning uses different forms and tools for working with students, teamworking and individual work. Effective balancing of such forms and tools is the basis of the success of blended learning methods. The task of the teacher is to identify the main topics of the course and to find the best practice scenarios for their study. Traditional lectures, video materials, closed tests should be 
main text of the paper is removed... 
introduction of open distance courses and their use in educational processes of mixed learning.

\section{References}

[1] Kukharenko V. M., Berezenska S. M., Buhaichuk K. L., Oliinyk N. Iu., Oliinyk T. O., Rybalko O.V., Syrotenko N. H., Stoliarevska A. L. (2016) Teoriia i praktyka zmishanoho navchannia: monohrafiia [Theory and practice of mixed learning: a monograph]. Kharkiv: "Miskdruk", HTU "HPI" (in Ukrainian).

[2] Wendy W. Porter, Charles R. Graham, Kristian A. Spring, Kyle R. Welch_(2014) Blended learning in higher education: Institutional adoption and implementation. Computers \& Education, vol. 75, pp. 185195.

[3] 10 Drivers Of Blended Learning In Education. Available at: https://www.teachthought.com/learning/10-drivers-of-blended-learningin-education/ (accessed 25 March 2018).

[4] Avtory elektronnoi systemy upravlinnia VUZom Sokrat (The authors of electronic control system by Institute of higher Sokrat). Available at: goo.gl/1csJ7S (accessed 8 April 2018).

[5] Sait publikatsii ta elektronnykh materialiv Khabrakhabr (Site of Khabrakhabr publications and electronic materials). Available at: https:// habrahabr.ru/ (accessed 29 March 2018).

[6] Coursera Online Courses from Top Universities. Join for Free. Available at: https.//www.coursera.org/ (accessed 30 March 2018).

[7] Prometheus - masovi bezkoshtovni onlain-kursy (Prometheus is the mass free on-line courses). Available at: https://prometheus.org.ua/. (accessed 3 April 2018).

[8] Hrabko V. V., Romanyuk O. N., Bisikalo O. V., Bocula M. P., Palamarchuk Ye. A., Kovalenko O. O. Computer program «System of integration of electronic resources of higher educational establishment the electronic resources of VNTU JETIQ are «Computer-integrated («IER VNTU JETIQ»). The Registration License of copyright on the work, no. 72970 UA, 2017 (In Ukraine).

[9] Hazman O. S., Poliakov S. D. (2016) Pokolenye «Y»: metodolohyia vzaymodeistvyia $\mathrm{v}$ obrazovatelnoi crede [Generation of «Y»: the methodology of cooperation in an educational environment]. Rossijskoamerikanskij forum obrazovaniya [Russian-American education forum] (electronic journal), vol. 1(8). Available at: http://www.rusameeduforum.com/content/ru/?task=art\&article $=1001170 \&$ iid $=24$. (accessed 12 April 2018).

[10] Web design personas - best practices and examples. Available at: http:// www.smartinsights.com/marketplace-analysis/customer-analysis/webdesign-personas/ (accessed 12 April 2018).

[11] Pochebut M. Krizis IT-obrazovaniya - kak byt kompaniyam i molodym specialistam (Crisis of IT-education - how to be companies and young specialists). Available at: https://dou.ua/lenta/columns/education-andcareer/ (accessed 8 April 2018).

[12] Kovalenko O. O. (2012) Metodologiya proektirovaniya informacionnyh sistem organizacii - koncepciya dvuh dzerkal [Methodology of planning of the informative systems of organization is conception of two mirrors]. Rossijskij akademicheskij zhurnal [Russian academic magazine], vol. 4(22), pp. 38-41.

[13] Proektnyj metod v obrazovanii (A project method is in the education). Available at: https://ailev.livejournal.com/1359563.html / (accessed 6 April 2018).

[14] Projects-vs-project-based-learning-what-is-the-difference. Available at: https://eduadventures.wordpress.com/2017/05/10/projects-vs-projectbased-learning-what-is-the-difference/ (accessed 12 April 2018).

[15] Kovalenko O. O., Melnyk Ye. O. (2017) Osoblyvosti vykorystannia instrumentiv zmishanoho navchannia $\mathrm{v}$ dystsyplini «Kompiuterni merezhi v systemakh upravlinnia» (Features of using instruments of the mixed studies in discipline the «Computer networks in control system») Available at: https://conferences.vntu.edu.ua/index.php/all-fksa/all-fksa2017/paper/view/3110/ (accessed 11 April 2018).
[16] Palamarchuk Ye. A., Bisikalo O. V., Kovalenko O. O. Computer program «Personal Repository». The Registration License of copyright on the work, no. 72969 UA, 2017 (In Ukraine).

[17] Palamarchuk Ye. A., Bisikalo O. V., Kovalenko O. O. Computer program «Navigator of educational resources». The Registration License of copyright on the work, no. 72967 UA, 2017 (In Ukraine).

[18] Hrabko V. V., Bisikalo O. V., Savchuk T. O., Palamarchuk Ye. A., Kovalenko O. O. Computer program «the Electronic dean office of JETIQ» («ED JETIQ»). The Registration License of copyright on the work, no. 72971 UA, 2017 (In Ukraine). 